\title{
ISLAMISASI ILMU EKONOMI
}

\author{
Irfan Syauqi Beik \\ Center of Islamic Business and Economic Studies, \\ Institut Pertanian Bogor
}

\begin{abstract}
Abstrak. Islamisasi Ilmu Ekonomi. Islam merupakan ajaran yang mencakup seluruh bidang kehidupan. Tantangan terbesar saat ini adalah bagaimana mengekstraksi prinsip-prinsip ekonomi dalam Al-Qur'an dan hadits, kemudian menurunkannya menjadi sebuah body of knowledge sekaligus membangunnya menjadi sebuah disiplin ilmu yang secara teoritis dan praktis berbeda signifikan dengan mazhab-mazhab ilmu ekonomi konvensional yang ada. Namun muncul kritik bahwa ekonomi syariah hanya "mengekor" ekonomi konvensional semata, sehingga orisinalitas keilmuannya sering dipertanyakan. Dalam proses islamisasi ekonomi, yang telah dilakukan, yaitu melaui pengembangan alat ukur kesejahteraan dan kemiskinan yang didasarkan pada konsep syariah dengan Model CIBEST. Model CIBEST adalah upaya untuk mengembangkan pendekatan kesejahteraan kemiskinan yang didasarkan pada konsepsi bahwa alat untuk mengukur kesejahteraan dan kemiskinan tidak semata mata didasarkan pada material semata, namun juga pendekatan spiritual. Hal ini didasarkan pada konsep pemenuhan kebutuhan, dimana al-Quran dan Hadis telah menggariskan bahwa pada dasarnya kebutuhan manusia terdiri atas dua hal, yaitu kebutuhan material dan spiritual.
\end{abstract}

Kata Kunci: Islamisasi, Material, CIBEST.

Abstract. Islamization of Economics. Islamic doctrine teaches all areas of human life. How to extract economic principles in the Qur'an and hadith are the biggest challenge todays, and then makes it into a body of knowledge as well to build it into a theoretically and practically discipline that differ significantly from the schools of the existing the conventional economics. But the critique and issue come up those Islamic financial services only "follow" the conventional economics, so the scientific originality is often questionable. In the process of Islamization economy, which has been carried out, namely through the development of well-being and poverty measurement tool that is based on the concept with CIBEST Model. CIBEST Model is an effort to develop a welfare approach to poverty based on the conception that a tool to measure well-being and poverty are not solely based on purely material, but also spiritual approach. It is based on the concept of fulfillment, where the al-Qur'an and Hadith has outlined those basically human needs consists of two things, the material and spiritual needs.

Keywords: Islamization, Material, CIBEST. 


\section{Pendahuluan}

Ekonomi sesungguhnya merupakan bagian yang tidak terpisahkan dari ajaran Islam, karena Islam pada hakekatnya merupakan ajaran yang bersifat syumuliyah, yaitu mencakup seluruh bidang kehidupan. Pada dasarnya, pembahasan hal-hal yang berkaitan dengan prinsip Islam dalam bidang ekonomi telah menarik perhatian para ulama dan ilmuwan muslim, berabad-abad sebelum Adam Smith mempublikasikan bukunya yang berjudul An Inquiry into the Nature and Cause of the Wealth of Nations, sebuah karya yang dianggap sebagai milestone pembangunan ilmu dan sistem ekonomi kapitalis. Bahkan Sadeq dan Ghazali (1992) ${ }^{1}$ menyatakan bahwa perkembangan pemikiran ekonomi Islam sesungguhnya sama tuanya dengan perkembangan Islam itu sendiri.

Al-Qur'an dan as-Sunnah, meskipun bukan merupakan buku teks ekonomi, namun mengandung berbagai prinsip dasar ekonomi yang dapat diaplikasikan dalam kehidupan. Pada sebuah penelitian yang dilakukan oleh International Islamic University Islam abad Pakistan, terungkap bahwa ayat-ayat al-Qur'an yang memiliki hubungan langsung dengan ekonomi, diperkirakan berjimlah sekitar \pm 400 -an ayat, atau setara dengan 3,5 juz (Hafidhuddin, 2007)2². Belum lagi ditambah dengan haditshadits muamalah, yang hingga saat ini belum ada penelitian mengenai berapa jumlah pasti hadits-hadits tersebut. Hal ini menunjukkan bahwa ajaran Islam memiliki perhatian yang sangat serius terhadap persoalan ekonomi.

Dalam konteks saat ini, kesadaran umat Islam untuk mulai menerapkan kembali ajaran Islam dalam bidang ekonomi, telah membawa lembaga-lembaga ekonomi Islam, seperti perbankan dan keuangan syariah, pada pertumbuhan yang sangat luar biasa, terutama dalam empat dasawarsa terakhir ini. Hal tersebut menyiratkan bahwa ekonomi dan keuangan Islam memiliki prospek dan masa depan yang sangat cerah. Bukan tidak mungkin, sistem ekonomi Islam yang sedang dibangun saat ini, dapat menggantikan dominasi sistem ekonomi konvensional.

Namun demikian, pesatnya pertumbuhan institusi ekonomi dan keuangan syariah ini belum diikuti oleh peningkatan kualitas pendidikan ekonomi dan keuangan syariah yang terstruktur dan terstandarisasi secara global. Akibatnya, sering terjadi ketidaksinkronan antara harapan teoritis dengan realitas yang ada. Pada sisi pembangunan kurikulum, dominasi pemikiran mazhab Ekonomi Neoklasik 
Irfan Sauqi Beik: Islamisasi Ilmu Ekonomi

masih mempengaruhi struktur kurikulum yang ada, mulai pada aspek epistemologis, ontologis dan aksiologis. Sehingga, pola pengajaran ilmu ekonomi Neoklasik sering dijadikan sebagai benchmark dalam pengembangan arsitektur pengajaran ilmu ekonomi syariah ${ }^{3}$ yang ada.

Sebagian pakar berpendapat bahwa pengaruh tersebut adalah hal yang wajar mengingat perekonomian dunia saat ini didominasi oleh mazhab neoklasik. Dominasi ini bukan hanya mempengaruhi ilmu ekonomi syariah semata, namun juga mempengaruhi perkembangan ilmu ekonomi konvensional itu sendiri. Mazhabmazhab lain, terutama non-mainstream mazhab, yaitu heterodox economics tidak memiliki pengaruh seluas dan sekuat mazhab Neoklasik, yang pada dasarnya merupakan turunan dari mazhab Ekonomi Klasik (Classical Economics). Hal ini dapat dilihat dari struktur kurikulum pendidikan ilmu ekonomi yang diajarkan di fakultasfakultas ekonomi yang ada di tanah air, sehingga fakultas-fakultas ekonomi tersebut seharusnya diberikan label tambahan sebagai Fakultas Ekonomi Neoklasik. Adapun mazhab-mazhab lain, sering kali hanya menjadi pelengkap. Sebagai contoh, mazhab Institutional Economics hanya diberikan tempat sebagai satu matakuliah tersendiri, yaitu matakuliah Ekonomi Kelembagaan di fakultas-fakultas ekonomi yang ada di tanah air, meski tidak semua FE mengajarkannya.

Oleh karena itu, tantangan terbesar saat ini adalah bagaimana mengekstraksi prinsip-prinsip ekonomi dalam Al-Qur'an dan hadits, kemudian menurunkannya menjadi sebuah body of knowledge yang utuh, sekaligus membangunnya menjadi sebuah disiplin ilmu yang secara teoritis dan praktis berbeda signifikan dengan mazhab-mazhab ilmu ekonomi konvensional yang ada. Terkait dengan hal ini maka isu yang kemudian muncul adalah isu metodologi: bagaimana pendekatan metodologi dalam membangun dan mengembangkan ilmu ekonomi syariah itu dilakukan?

\section{Metodologi Ilmu Ekonomi Syariah}

Menurut Prof Zubair Hassan (1998)4, ada dua pendekatan metodologi yang selama ini digunakan dalam membangun ilmu ekonomi syariah. Pertama adalah allor-nothing approach, yaitu pendekatan yang berpegang pada prinsip "syariah total atau tidak syariah sama sekali". Pada pendekatan ini, seluruh teori dan konsep ekonomi konvensional dinegasikan dan diruntuhkan, kemudian dibangunlah ilmu 
Islamiconomic: Jurnal Ekonomi Islam Vol.7 No.2 Juli - Desember 2016

ekonomi syariah dengan definisi dan konseptualisasinya sendiri. Akan tetapi, kelemahan pendekatan ini seringkali tidak aplikatif dan sulit direalisasikan.

Adapun pendekatan kedua adalah step by step approach, yaitu pendekatan gradual, tahap demi tahap. Dalam pendekatan ini, terjadi proses filterisasi ilmu ekonomi konvensional dengan mengeliminasi komponen-komponen yang bertentangan dengan ajaran Islam. Namun demikian, meski aplikatif, kelemahan pendekatan ini adalah munculnya kritik bahwa ekonomi syariah hanya "mengekor" ekonomi konvensional semata, sehingga orisinalitas keilmuannya sering dipertanyakan.

Dalam prakteknya, fakta menunjukkan pendekatan yang kedua lebih dominan bila dibandingkan dengan pendekatan yang pertama. Namun, yang kemudian menjadi masalah dan sering mendapat kritik adalah ketidakmampuan para ekonom Islam untuk berpikir out of the box. Maksudnya, struktur ekonomi Islam sering kali didesain mengikuti struktur ekonomi konvensional dengan kerangka berpikir yang tidak terlalu berbeda, sehingga terkadang agak sulit membedakan keduanya. Akibatnya banyak yang kemudian berpendapat bahwa ekonomi Islam adalah ekonomi konvensional minus riba plus zakat dan bagi hasil. Padahal tidak sesederhana itu.

Oleh karena itu, merujuk pada fakta dominasi pendekatan yang kedua, maka pilihan yang paling rasional dan applicable saat ini adalah dengan melakukan Islamisasi ilmu ekonomi melalui pendekatan yang bersifat integratif. Pendekatan integratif ini maksudnya adalah dengan menjadikan ilmu ekonomi konvensional sebagai benchmark, dan kemudian dilakukan modifikasi dan insersi nilai-nilai Islam sehingga melahirkan ilmu ekonomi syariah yang memiliki perbedaan dengan ilmu ekonomi konvensional, baik dari sisi filosofis maupun dari sisi praktis.

Menurut Mohammed Aslam Haneef ${ }^{5}$, Guru Besar International Islamic University Malaysia, kriteria integrasi dan Islamisasi ilmu ekonomi ini ada 5, yaitu:

1. No integration : pendekatannya murni konvensional

2. Minor integraion : Islamic input dalam ilmu ekonomi berkisar antara 1-20 persen

3. Moderate integration : islamic input dalam ilmu ekonomi berkisar antara 2140 persen

4. Comparative-based integration : Islamic input dalam ilmu ekonomi berkisar antara 41-70 persen 
Irfan Sauqi Beik: Islamisasi Ilmu Ekonomi

5. Complete Islamic economics : Islamic input dalam ilmu ekonomi lebih dari 70 persen

Dari kriteria tersebut diharapkan kurikulum ekonomi dan keuangan syariah berada, paling tidak, pada level keempat, yaitu comparative-based integration. Yang paling ideal tentu saja pada level kelima, yaitu complete Islamic economics. Integrasi ini diharapkan dapat dititikberatkan pada dua aspek pengetahuan utama, yaitu:

1. Substantive knowledge : yaitu konseptualisasi dan teorisasi ilmu ekonomi syariah

2. Technical knowledge : yaitu ilmu-ilmu alat yang digunakan dalam mengkonstruksi ilmu ekonomi syariah

\section{Islamic Worldview}

Terkait dengan substantive knowledge ini, karena ia adalah intisari dari ilmu ekonomi syariah, maka landasan filosofis yang menjadi pondasi dasar ilmu ekonomi syariah haruslah dibangun di atas worldview yang Islami. Worldview atau cara pandang ini merupakan konsep dasar yang sangat strategis, yang bisa membedakan antara ilmu ekonomi syariah dengan ilmu ekonomi konvensional. Worldview ini pula yang nantinya membedakan muatan "nilai" yang diajarkan oleh ilmu ekonomi konvensional dengan ilmu ekonomi syariah.

Aspek "nilai" ini menjadi sangat penting karena tidak ada satu cabang ilmu yang bebas nilai. Meyakini "bebas nilai" ini juga pada dasarnya merupakan 'nilai". Yaitu, nilai yang bebas nilai. Ilmu ekonomi adalah value-loaded science, yaitu ilmu yang sarat nilai. Tinggal sekarang yang menjadi pertanyaan adalah, nilai apa yang dianut dan diajarkan oleh ilmu ekonomi? Terkait dengan hal ini, maka konstruksi nilai ilmu ekonomi syariah haruslah berbeda nyata dengan konstruksi nilai pada ilmu ekonomi konvensional. Disinilah urgensi kita untuk memahami konsep worldview yang melatarbelakangi pembentukan ilmu ekonomi konvensional dengan ilmu ekonomi syariah. Di atas konsep worldview inilah maka seluruh teori pada ilmu ekonomi konvensional maupun ilmu ekonomi syariah dibangun. 
Islamiconomic: Jurnal Ekonomi Islam Vol.7 No.2 Juli - Desember 2016

Paling tidak, konsep worldview pada ilmu ekonomi syariah dan ilmu ekonomi konvensional berbeda pada 6 aspek, yaitu :

\section{Konsep Tuhan}

Konsep Tuhan adalah konsep yang paling fundamental. Pada ilmu ekonomi konvensional, Tuhan tidak diperkenankan untuk melakukan intervensi terhadap teorisasi ilmu ekonomi konvensional. Apalagi pasca Vienna Ciecle tahun 1992, para ekonom konvensional sepakat bahwa nilai-nilai ketuhanan adalah nilai-nilai normatif yang tidak boleh dijadikan sebagai dasar pembentukan teori, kecuali telah diverifikasi secara faktual. Dengan kata lain, selama belum dapat dibuktikan secara empiris, maka nilai-nilai normatif ini belum bisa dijadikan sebagai dasar acuan teoritis.

Hal ini tentu saja berbeda dengan ilmu ekonomi syariah dimana konsep ketuhanan ini memegang peranan yang sangat fundamental. Disinilah peran konsep Tauhid sebagai pondasi bangunan ilmu ekonomi syariah. Allah adalah Tuhan yang seluruh perintah dan larangan-Nya harus dijadikan sebagai rujukan dasar dalam membangun teori-teori yang ada. Konsep tauhid ini harus terefleksikan dalam bangunan keilmuan yang dibangun. Tidak boleh ada satu pun klausul konsep dan teori dalam ilmu ekonomi syariah yang bertentangan dengan konsep tauhid ini, baik tauhid rububiyah, tauhid uluhiyah, maupun tauhid asma wa sifat.

Sebagai contoh, dalam konsep tauhid, diantara nama Allah adalah Ar Razzaq, atau Sang maha Pemberi Rizki. Allah SWT-lah yang menjamin rezeki seluruh makhluk-Nya. Implikasi dari konsep ini adalah pada konsep kelangkaan atau scarcity. Konsep inilah yang menjadi justifikasi perlunya ilmu ekonomi. Dalam perspektif konvensional, kelangkaan yang muncul adalah absolute scarcity, yaitu keterbatasan sumber daya yang ada, sehingga manusia, dalam memenuhi keinginannya yang tidak terbatas, harus melakukan pilihan. Pilihan-pilihan tersebut adalah what to produce? How to produce? Dan for whom to produce? 
Irfan Sauqi Beik: Islamisasi Ilmu Ekonomi

Dalam Islam, kelangkaan absolut ini tidak dapat diterima. Dasar argumentasinya adalah karena Allah telah menjamin segalanya. Namun demikian, kita masih melihat fakta banyaknya orang yang masih kelaparan dan mereka tidak mampu memenuhi kebutuhan hidupnya secara layak. Karena itu, dalam ilmu ekonomi syariah, konsep yang bisa diterima adalah kelangkaan relatif atau relative scarcity. Terjadinya kelangkaan relatif ini bisa disebabkan oleh beberapa hal, yaitu : (1) pengetahuan manusia yang terbatas dalam mengelola sumberdaya sehingga ini mempengaruhi cara kerja manusia dalam memanfaatkan semberdaya yang ada; dan (2) sistem ekonomi yang dibangun di atas prinsip kezaliman dan ketidakadilan sehingga sebagian masyarakat tidak bisa mengakses sumberdaya ekonomi yang ada. Akibatnya, terjadilah kelaparan, kesenjangan pendapatan dan kemiskinan secara sistemik.

\section{Konsep Agama}

Peran agama dalam ilmu ekonomi syariah sangat signifikan, karena agama Islam adalah referensi ilmu ekonomi syariah. Berbeda dengan ilmu ekonomi konvensional yang tidak didasarkan pada ajaran agama. Agama adalah candu, sehingga ilmu ekonomi konvensional tidak memerlukan agama dalam membangun teori-teori yang ada. Inilah bentuk sekulerisasi yang ada di Barat. Hal ini wajar mengingat sejarah masa lalu mereka yang terekam dalam masamasa kegelapan (the dark ages), dimana mereka menyalahkan agama mereka sebagai biang kerok masa ketertinggalan tersebut.

Sementara dalam ilmu ekonomi syariah, fungsi agama sedemikian kuat karena ilmu ekonomi syariah adalah ilmu yang didasarkan pada ajaran agama Islam, yang bersifa universal. Tanpa Islam, tidak mungkin ada ilmu ekonomi syariah. Ini adalah bagian dari keyakinan dimana islam diyakini adalah ajaran yang bersifat syumuliyah atau komprehensif. Artinya, mencakup seluruh bidang kehidupan. Tidak ada satu pun bidang kehidupan yang tidak diatur oleh Islam, termasuk ekonomi. 


\section{Konsep Manusia}

Faktor ketiga yang membedakan konsep worldview pada ilmu ekonomi konvensional dan ilmu ekonomi syariah adalah konsep manusia yang digunakan. Ilmu ekonomi adalah ilmu yang mempelajari human behavior atau perilaku manusia dalam memenuhi kebutuhan hidupnya, baik perilaku individual dalam konteks mikro, maupun perilaku secara kolektif dalam konteks makro. Semua ini bergantung pada prototipe manusia seperti apa yang digunakan oleh masing-masing ilmu ekonomi.

Pada ilmu ekonomi konvensional, yang digunakan adalah konsep homo economicus. Yaitu konsep manusia yang didasarkan pada prinsip self interest, atau memaksimalkan kepentingan dirinya. Sehingga, semua teori yang diajarkan itu didasarkan kepada kepentingan manusia secara individual, dan perilaku masyarakat pada dasarnya merupakan agregasi dari perilaku individual.

Sebagai contoh adalah teori konsumsi (lihat pembahasan detailnya dalam Beik dan Arsyianti, 2016) ${ }^{6}$. Dalam teori konsumsi konvensional, orientasi akhirnya adalah bagaimana menggapai maximum satisfaction atau maximum utility. Yaitu, bagaimana kita memaksimalkan kepuasan. Ini adalah realisasi dari konsep self interest. Kondisi utilitas maksimal ini tercapai ketika manusia bisa mengkombinasikan konsumsi barang dan jasa yang memberikan kepuasan maksimal dengan batasan garis anggaran. Secara grafis, ini terjadi ketika kurva yang menggambarkan kombinasi barang dan jasa yang memberikan kepuasan maksimal, dan garis anggaran adalah pendapatan yang siap dibelanjakan oleh konsumen.

Dari konsep ini dapat diketahui bahwa ukuran kepuasan yang harus diraih manusia adalah ukuran self consumption, atau konsumsi sendiri. Sehingga, ketika seseorang akan berbagi dengan orang lain, maka ia tidak akan bisa memaksimalkan kepuasannya secara grafis dan matematis. Karena itu, konsep berbagi pasti akan bertentangan dengan konsep maximum utility. 
Pertanyaan berikutnya, jika berbagi itu dianggap bagian dari maximum utility, maka berarti konsepnya sebenarnya menjadi Islami? Jawabannya sederhana, tidak. Hal ini dikarenakan oleh formulasi teori konsumsi secara grafis dan matematis yang tidak memberi ruang pada berbagi. Semuanya harus dihabiskan untuk diri sendiri. Bahkan keseimbangan teori konsumsi ini tercapai ketika marginal utility dari mengkonsumsi barang pertama dibagi dengan barang kedua, sama dengan perbandingan harga dari kedua barang tersebut.

Ini tentu saja berbeda dengan ilmu ekonomi syariah dimana prototipe manusianya didasarkan pada konsep nafsul muthmainnah. Dengan konsep ini maka orientasi manusia bukanlah pada self interest, namun pada falah. Falah adalah konsep dimana tujuan hidup manusia yang sebenarnya adalah menggapai kebahagiaan dunia dan akherat (al hasanah fid dunya wal aakhirah), sehingga manusia akan berusaha menjadi falah maximizer.

Dalam konteks teori konsumsi, ketika orientasinya adalah untuk mencapai maximum falah, maka di dalam melakukan konsumsinya, seseorang tidak hanya memikirkan dirinya, namun juga orang lain. Sehingga, semangat berbagi menjadi bagian integral dari perilaku konsumsi seseorang. Seorang falah maximizer akan senantiasa mempertimbangkan apakah konsumsi yang dilakukannya memberikan kemslahatan bagi diri dan lingkungannya, atau justru malah menciptakan kerusakan bagi diri dan lingkungannya. Dengan uang yang dimilikinya, ia akan berusaha menciptakan kemanfaatan yang sebesar-besarnya.

Inilah contoh perbedaan bagaimana konsep manusia ternyata menciptakan perbedaan teori dan bangunan ilmu. Masih banyak contoh lainnya, seperti teori produksi konvensional yang berorientasi pada maximum profit dan teori produksi syariah yang berorientasi pada maximum falah. 


\section{Konsep Pengetahuan}

Faktor keempat yang membedakan ilmu ekonomi syariah dengan ilmu ekonomi konvensional terletak pada sumber pengetahuan. Secara epistemologis keduanya berbeda. Sumber rujukan tertinggi pada ilmu ekonomi syariah adalah Al Qur'an dan hadits. Berbeda dengan ilmu ekonomi konvensional yang didasarkan pda perpaduan antara rasionalisme dengan empirisme.

Pengetahuan logis yang bersumber dari logika akal dan pembuktian secara empiris, adalah sumber rujukan tertinggi bagi ekonomi konvensional. Begitu logika dan fakta empirisnya berubah, maka berubah pula teorinya. Bahkan jika terjadi kontradiksi sekalipun. Karena itu, mazhab-mazhab dalam ilmu ekonomi konvensional kadang-kadang bertentangan secara diametral antara satu dengan lainnya.

Adapun dalam Islam, segala yang bertentangan dengan Al Quran dan hadits akan tertolak. Fungsi akal adalah bagaimana menerjemahkan maksud ayat dan hadits san menurunkannya menjadi teori ekonomi. Jika realitas yang ada bertentangan dengan perintah Al Quran, maka tugas akal adalah bagaimana kemudian mencari penyebab dan memberikan solusinya agar realitas bisa semakin mendekati perintah Al Quran. Bukan sebaliknya, mengubah Al Quran demi kepentingan realitas ekonomi.

\section{Konsep Alam}

Selanjutnya adalah konsep alam semesta, dimana dalam ilmu ekonomi syariah, alam ini diciptakan untuk kepentingan manusia. Tinggal bagaimana manusia menata hubungannya dengan alam sehingga kondisi alam tetap berada pada dalam dan jauh dari ekploitasi yang merusak.

Berbeda dengan ilmu ekonomi konvensional yang menjadikan alam sebagai objek utama kegiatan ekonomi manusia. Dalam prakteknya, terjadi eksploitasi berlebihan yang menciptakan kerusakan lingkungan. Barulah pada tiga dekade 
terakhir muncul isu pemanasan global dan perubahan lingkungan, sehingga gagasan green economy menjadi sangat kuat akhir-akhir ini. Sementara dalam ajaran Islam, pengeturan lingkungan ini sudah menjadi bagian yang muncul secara otomatis dalam kajian-kajian ilmu ekonomi syariah.

\section{Konsep Tujuan Hidup}

Terakhir adalah konsep tujuan hidup. Dimensi ilmu ekonomi konvensional dan ilmu ekonomi syariah sangat berbeda dari sisi tujuan hidup. Ilmu ekonomi konvensional hanya berbicara tentang dunia semata, sementara ilmu ekonomi syariah, dimensi itu diperluas hingga dimensi akherat, yang bagi sebagian orang masih dianggap abstrak.

Adanya konsep falah sebagai the ultimate objective of Islamics economics mengindikasikan bahwa ekonomi adalah disiplin ilmu tidak sebatas mengajarkan bagaimana menggapai keberhasilan dunia, melainkan juga keberhasilan di akherat. Karena itu, ilmu ekonomi syariah menjadi sangat sensitif terhadap berbagai konsep yang secara diametral bertentangan dengan ketentuan Allah dan Rasul-Nya, meski secara ekonomis boleh jadi menguntungkan, karena akan mempengaruhi keberhasilan pencapaian manusia di akherat kelak.

Misalnya, definisi harta obyek pajak dalam ilmu ekonomi konvensional adalah segala jenis harta yang memiliki nilai ekonomis, tanpa mempedulikan halal dan haram. Dalam ilmu ekonomi syariah, hal ini tidak dapat diterima karena aspek halal dan haram adalah isu sentral yang strategis.

Demikian pula dengan konsep bunga yang secara ekonomis dapat memberikan keuntungan bagi pemegang modal, dan dapat berfungsi sebagai insrumen yang mengatur keseimbangan sektor riil dan sektor moneter. Dalam Islam, haramnya bunga bersifat mutlak karena bunga adalah riba. Karena itu, bunga tidak dapat dijadikan sebagai instrumen untuk menyeimbangkan sektor 
Islamiconomic: Jurnal Ekonomi Islam Vol.7 No.2 Juli - Desember 2016

riil dan sektor moneter. Faktanya, bunga terbukti menjadi instrumen yang menciptakan beragam krisis dan instabilitas perekonomian.

\section{Agenda Islamisasi Ilmu Ekonomi}

Dengan melihat karakteristik worldview antara ilmu ekonomi konvensional dengan ilmu ekonomi syariah, maka tentu bangunan keilmuannya akan berbeda. Tugas kita ke depan adalah bagaimana mentransformasikan sistem ekonomi yang ada saat ini menjadi sistem ekonomi yang sesuai dengan tuntunan ajaran Islam. Untuk itu, diperlukan adanya penguatan dari sisi keilmuan karena ilmu adalah pondasi dasar peradaban.

Dalam konteks inilah maka upaya Islamisasi ilmu ekonomi menjadi salah satu pekerjaan rumah yang sangat menantang. Untuk itu, sejumlah agenda harus mendapatkan perhatian kita semua agar proses Islamisasi ini berjalan dengan baik.

Agenda pertama adalah perlunya integrasi yang lebih mendalam antara ilmu ekonomi dengan ilmu-ilmu Dirasah Islamiyah. Ada beberapa cabang ilmu Dirasah Islamiyah yang dirasakan sangat penting untuk diintegrasikan secara lebih mendalam, yaitu: ilmu Al-Quran, ilmu Al-Hadits, ilmu'Aqidah, ilmu al-ushul, Fiqh Muamalah, dan sejarah Islam (Hafidhuddin, 2007)7.

Agenda kedua, perlunya penguatan institusi dan kurikulum pendidikan, baik pendidikan dasar dan menengah maupun perguruan tinggi, sebagai garda terdepan dalam pengembangan ilmu ekonomi syariah. Hingga saat ini, belum ada satu pun negara Islam di dunia yang memiliki kurikulum yang komprehensif tentang ekonomi syariah. Yusuf Qardlawi mengusulkan agar pendidikan yang bersifat fardhu 'ain diajarkan pada tingkat dasar dan menengah, sedangkan tugas universitas dan lembaga pendidikan tinggi lainnya adalah mengajarkan pendidikan yang bersifat fardhu kifayah, seperti ekonomi, politik, dan lain-lain. Pola yang seperti ini akan mengurangi kemungkinan disintegrasi ilmu dunia dan ilmu agama sebagaimana yang terjadi saat ini. Seolah-olah keduanya merupakan dua kutub yang terpisah. Padahal dalam Islam, dikotomi semacam itu tidak dikenal (Beik, 2008)8 .

Penulis pun mengusulkan untuk melakukan kajian secara mendalam tentang perlunya memiliki ilmu semacam ushul fiqh dalam ekonomi syariah, yaitu ushul iqtishad. Jika merujuk pada fiqih-fiqih madzhab yang ada, maka dapat disimpulkan 
Irfan Sauqi Beik: Islamisasi Ilmu Ekonomi

bahwa meskipun mereka memiliki perbedaan pendapat dalam kasus-kasus tertentu, namun mereka memiliki standar tertentu yang harus dipenuhi dalam proses penentuan hukum atas suatu kasus atau peristiwa tertentu. Standar itulah yang disebut dengan ilmu ushul fiqh.

Hingga saat ini, kaidah standar yang disepakati oleh para ekonom syariah sebagaimana kaidahnya para fuqaha, masih belum dimiliki. Di atas kaidah standar itulah maka ekonomi syariah dibangun dan dikembangkan. Padahal jika melihat ilmu ekonomi konvensional, meskipun ada banyak madzhab di dalamnya, namun mereka memiliki titik singgung, paradigma, dan kaidah standar yang disepakati. Misalnya, posisi teori persaingan sempurna dalam bangunan ilmu ekonomi konvensial. Meskipun banyak kritik terhadap teori tersebut, namun ternyata ia telah telah menjadi prinsip yang paling dasar dalam pengembangan ilmu ekonomi konvensional. Inilah yang belum disepakati dalam ilmu ekonomi syariah. Akibatnya, seseorang bisa saja berbeda secara diametral dalam mendefinisikan ilmu ekonomi syariah dengan orang atau pihak yang lain.

Alasan lainnya adalah, karena sumber rujukan tertinggi ilmu ekonomi syariah adalah Al-Qur'an dan Sunnah, maka jika tidak ada kaidah standar yang disepakati, peluang perbedaan interpretasi yang berujung pada perbedaan derivasi atau turunan teori ekonomi Islam menjadi sangat besar. Demikian pula dengan persoalan ekonomi positif dan ekonomi normatif, yang juga terkadang menjadi masalah dalam membangun ilmu ekonomi syariah. Apakah ekonomi Islam itu adalah ilmu normatif, ilmu positif, atau kombinasi diantara keduanya. Disinilah pentingnya peran universitas dan lembaga pendidikan untuk terus menerus melakukan kajian atau riset dalam menentukan kaidah standar.

Agenda ketiga adalah membangun infrastruktur yang dapat menjadi laboratorium empiris bagi riset dan pengembangan ekonomi syariah. Infrastruktur ini termasuk penguatan institusi-institusi ekonomi Islam, seperti lembaga zakat, perbankan syariah, pasar modal syariah, dan lain-lain. Bagaimanapun juga, tanpa kinerja nyata yang ditunjukkan oleh institusi-institusi ekonomi Islam, maka pengembangan teori ekonomi Islam akan mengalami hambatan dan proses stagnasi. Ini adalah pekerjaan rumah yang harus diselesaikan oleh seluruh komponen umat Islam dunia. 
Islamiconomic: Jurnal Ekonomi Islam Vol.7 No.2 Juli - Desember 2016

Contoh Aplikasi Islamisasi Ilmu Ekonomi: Model CIBEST sebagai Alat Ukur Kesejahteraan dan Kemiskinan dalam Ekonomi Pembangunan Syariah.

Sebagai bagian terakhir dari makalh ini, penulis mencoba untuk memberikan proses islamisasi ekonomi, yang telah penulis lakukan, yaitu melaui pengembangan alat ukur kesejahteraan dan kemiskinan yang didasarkan pada konsep syariah alat ukur ini diberi Model CIBEST, yang dikembangkan oleh Beik dan Arsyianti (2015) ${ }^{9}$. Ini adalah bagian dari mata kuliah ekonomi pembangunan syariah yang dikembangkan oleh program Studi S1 ilmu ekonomi syariah FEM IPB.

Model CIBEST adalah upaya untuk mengembangkan pendekatan kesejahteraan kemiskinan yang didasarkan pada konsepsi bahwa alat untk mengukur kesejahteraan dan kemiskinan tidak semata mata didasarkan pada material semata, namun juga pendekatan spiritual. Hal ini didasarkan pada konsep pemenuhan kebutuhan, dimana al-quran dan hadis telah menggariskan bahwa pada dasarnya kebutuhan manusia terdiri atas dua hal, yaitu kebutuhan material dan spiritual.

Sebagai contoh menurut Hafidhudin (2013) ${ }^{10}$, dan QS 20:118-120 dan QS 106:34 dijelaskan bahwa diantara kebutuhan pokok itu adalkah dapat melakukan ibadah; terpenuhi kebutuhan, sandang, pangan dan papan; serta kebutuhan serta rasa aman dan hilangnya rasa takut. Dalam konteks ini maka ada tiga kunci utama yang dijadikan sebagai landasan pokok dalam menentukan kebutuhan dasar, yaitu kebutuhan material (sandang, pangan dan papan) dan kebutuhan spiritual (pelaksanaan ibadah dan terbebas dari rasa takut). Ketidakmampuan dalam memenuhi kedua kebutuhan tersebut akan menyebabkan seseorang atau suatu keluarga masuk dalam kategori miskin material dan miskin spiritual.

Dalam model CIBEST, Beik dan Arsyianti (2015) kemudian membagi kondisi suatu rumah tangga atau keluarga ke dalam empat kemungkinan keadaan. Pertama, suatu rumah tangga memiliki kemampuan dalam memenuhi kedua kebutuhan tersebut, baik material maupun spiritual. Inilah yang disebut sebagai rumah tangga sejahtera. Artinya, pendapatan keluarga tersebut berada di atas garis kemiskinan material dan skor spiritualnya berada di atas garis kemiskinan spiritual.

Kedua, suatu rumah tangga hanya mampu memenuhi kebutuhan spiritual saja, tetapi tidak mampu memenuhi kebutuhan material. Rumah tangga seperti ini berada dalam kondisi kemiskinan material. Ketiga, suatu rumah tangga hanya mampu 196 
Irfan Sauqi Beik: Islamisasi Ilmu Ekonomi

memenuhi kebutuhan material, akan tetapi tidak mampu memenuhi kebutuhan spiritual mereka. Inilah yang disebut sebagai kelompok kemiskinan spiritual. Keempat, suatu rumah tangga tidak mampu memenuhi kedua kebutuhan tersebut, yaitu kebutuhan material maupun spiritual. Rumah tangga seperti ini berada pada kelompok kemiskinan absolut.

Berdasarkan konsepsi ini, maka Beik dan Arsyianti (2015) kemudian menyusun formula untuk menghitung indeks kesejahteraan, indeks kemiskinan material, indeks kemiskinan spiritual dan indeks kemiskinan absolut berdasarkan kuadran CIBEST. Kuadran CIBEST sendiri disusun berdasarkan empat kemungkinan keadaan sebagaimana telah dijelaskan di atas.

\section{Gambar 1 Kuandran CIBEST}

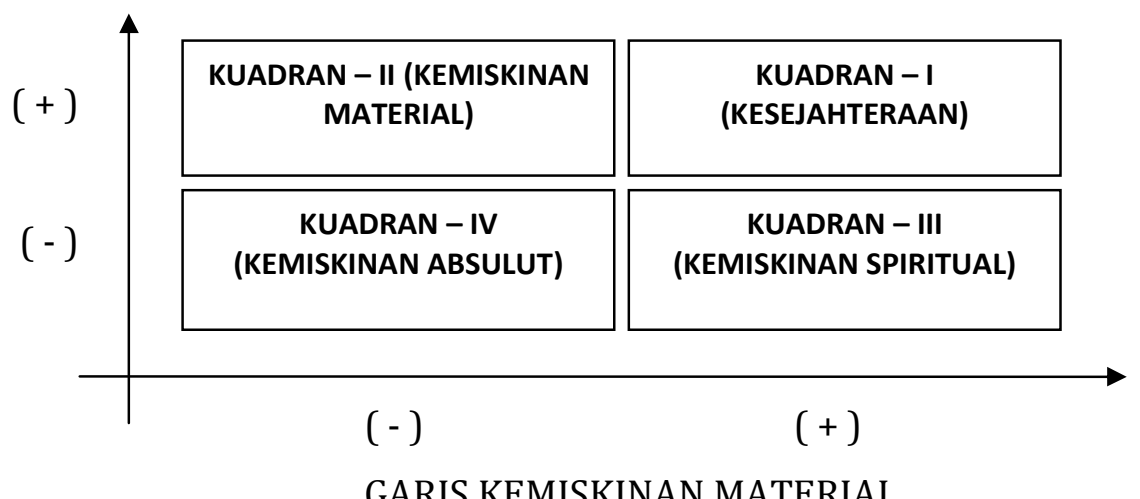

GARIS KEMISKINAN MATERIAL

\section{Sumber : Beik dan Arsyianti (2015)}

Adapun standar pemenuhan kebutuhan dasar spiritual didasarkan pada tiga kelompok variabel, yaitu : (i) pelaksanaan ibadah wajib yang terdiri atas shalat, puasa dan zakat dan infak; (ii) lingkungan keluarga dan (iii) kebijakan pemerintah. Shalat, puasa dan zakat adalah kewajiban dasar bagi setiap muslim. Ketidakmampuan melaksanakan ketiganya akan menyebabkan penurunan kualitas keimanan dan kondisi spiritualitas seseorang atau suatu rumah tangga.

Dimasukkannya lingkungan keluarga karena lingkungan yang baik akan sangat memengaruhi komitmen dan kesempatan dalam melaksanakan ibadah serta amal soleh lainnya pada setiap anggota keluarga. Dimasukkannya kebijakan pemerintah 
Islamiconomic: Jurnal Ekonomi Islam Vol.7 No.2 Juli - Desember 2016

karena terkait dengan pemberian rasa aman dan kebebasan dalam menjalankan ibadah serta membangun kesadaran beragama secara masif. Secara spesifik, Tabel 1 berikut menggambarkan indikator kebutuhan spiiritual.

Tabel 1. Indikator Kebutuhan Spiritual

\begin{tabular}{|c|c|c|c|c|c|c|}
\hline \multirow{2}{*}{ Variabel } & \multicolumn{5}{|c|}{ Skala Likert } & $\begin{array}{c}\text { Standar } \\
\text { Kemiskinan }\end{array}$ \\
\hline & 1 & 2 & 3 & 4 & 5 & \multirow{6}{*}{$\begin{array}{l}\text { Skor rata- } \\
\text { rata untuk } \\
\text { keluarga } \\
\text { yang secara } \\
\text { spiritual } \\
\text { miskin } \\
\text { adalah } 3 \text { (SV } \\
=3 \text { ) }\end{array}$} \\
\hline Shalat & $\begin{array}{l}\text { Melaran } \\
\text { g orang } \\
\text { lain } \\
\text { shalat }\end{array}$ & $\begin{array}{l}\text { Menolak } \\
\text { konsep } \\
\text { shalat }\end{array}$ & $\begin{array}{l}\text { Melaksan } \\
\text { akan } \\
\text { shalat } \\
\text { wajib } \\
\text { tidak } \\
\text { rutin }\end{array}$ & $\begin{array}{l}\text { Melaksanaka } \\
\text { n shalat wajib } \\
\text { rutin tapi } \\
\text { tidak selalu } \\
\text { berjamaah }\end{array}$ & $\begin{array}{l}\text { Melaksanak } \\
\text { an shalat } \\
\text { wajib rutin } \\
\text { berjamaah } \\
\text { dan } \\
\text { melakukan } \\
\text { shalat } \\
\text { sunnah }\end{array}$ & \\
\hline Puasa & $\begin{array}{l}\text { Melaran } \\
\text { g orang } \\
\text { lain } \\
\text { berpuas } \\
\text { a }\end{array}$ & $\begin{array}{l}\text { Menolak } \\
\text { konsep } \\
\text { puasa }\end{array}$ & $\begin{array}{l}\text { Melaksan } \\
\text { akan } \\
\text { puasa } \\
\text { wajib } \\
\text { tidak } \\
\text { penuh }\end{array}$ & $\begin{array}{l}\text { Hanya } \\
\text { melaksanaka } \\
\text { n puasa wajib } \\
\text { secara penuh }\end{array}$ & $\begin{array}{l}\text { Melaksanak } \\
\text { an puasa } \\
\text { wajib dan } \\
\text { puasa } \\
\text { sunnah }\end{array}$ & \\
\hline $\begin{array}{l}\text { Zakat dan } \\
\text { Infak }\end{array}$ & $\begin{array}{l}\text { Melaran } \\
\text { g orang } \\
\text { lain } \\
\text { berzaka } \\
\text { t dan } \\
\text { infak }\end{array}$ & $\begin{array}{l}\text { Menolak } \\
\text { zakat dan } \\
\text { infak }\end{array}$ & $\begin{array}{l}\text { Tidak } \\
\text { pernah } \\
\text { berinfak } \\
\text { walau } \\
\text { sesekali } \\
\text { dalam } \\
\text { setahun }\end{array}$ & $\begin{array}{l}\text { Membayar } \\
\text { zakat fitrah } \\
\text { dan zakat } \\
\text { harta }\end{array}$ & $\begin{array}{l}\text { Membayar } \\
\text { zakat fitrah, } \\
\text { zakat harta } \\
\text { dan } \\
\text { infak/sedek } \\
\text { ah }\end{array}$ & \\
\hline $\begin{array}{l}\text { Lingkunga } \\
\mathrm{n} \text { keluarga }\end{array}$ & $\begin{array}{l}\text { Melaran } \\
\text { g } \\
\text { anggota } \\
\text { keluarg } \\
\text { a } \\
\text { ibadah }\end{array}$ & $\begin{array}{l}\text { Menolak } \\
\text { pelaksan } \\
\text { aan } \\
\text { ibadah }\end{array}$ & $\begin{array}{l}\text { Mengang } \\
\text { gap } \\
\text { ibadah } \\
\text { urusan } \\
\text { pribadi } \\
\text { anggota } \\
\text { keluarga }\end{array}$ & $\begin{array}{l}\text { Mendukung } \\
\text { ibadah } \\
\text { anggota } \\
\text { keluarga }\end{array}$ & $\begin{array}{l}\text { Membangun } \\
\text { suasana } \\
\text { keluarga } \\
\text { yang } \\
\text { mendukung } \\
\text { ibadah } \\
\text { secara } \\
\text { bersama- } \\
\text { sama }\end{array}$ & \\
\hline $\begin{array}{l}\text { Kebijakan } \\
\text { pemerinta } \\
\text { h }\end{array}$ & $\begin{array}{l}\text { Melaran } \\
\text { g } \\
\text { ibadah } \\
\text { untuk } \\
\text { setiap } \\
\text { keluarg } \\
\text { a }\end{array}$ & $\begin{array}{l}\text { Menolak } \\
\text { pelaksan } \\
\text { aan } \\
\text { ibadah }\end{array}$ & $\begin{array}{l}\text { Mengang } \\
\text { gap } \\
\text { ibadah } \\
\text { urusan } \\
\text { pribadi } \\
\text { masyarak } \\
\text { at }\end{array}$ & $\begin{array}{l}\text { Mendukung } \\
\text { ibadah }\end{array}$ & $\begin{array}{l}\text { Menciptaka } \\
\mathrm{n} \\
\text { lingkungan } \\
\text { yang } \\
\text { kondusif } \\
\text { untuk } \\
\text { ibadah }\end{array}$ & \\
\hline
\end{tabular}

Sumber: Beik dan Arsyianti (2015) 
Irfan Sauqi Beik: Islamisasi Ilmu Ekonomi

Sedangkan kebutuhan material didasarkan pada analisis kebutuhan pokok yang harus dipenuhi. Kebutuhan ini antara lain termasuk kebutuhan makanan, pakaian, tempat tinggal, pendidikan, dan kesehatan. Selain itu, kebutuhan komunikasi dan transportasi juga dapat dimasukkan menjadi salah satu komponen kebutuhan material yang harus dipenuhi (Beik dan Arsyianti, 2015).

Rumus umum garis kemiskinan material menurut Beik dan Arsyianti (2015) adalah:

$$
\mathrm{MV}=\sum_{i=1}^{n} \quad \text { Pi Mi }
$$

Dimana:

MV : standar minimal kebutuhan material yang harus dipenuhi keluarga (Rp atau mata uang lain) atau disebut juga Garis Kemiskinan Material

Pi : Harga barang dan jasa (Rp atau mata uang lain)

Mi : Jumlah minimal barang dan jasa yang dibutuhakan

Sementara itu, untuk menghitung keseluruhan nilai spritual rumah tangga mustahik yang diamati, digunakan rumus sebagai berikut (Beik dan Arsyianti, 2015):

$$
S S=\sum_{k=1}^{n} \frac{\mathrm{SHk}}{\mathrm{N}}
$$

Dimana:

SS : Skor rata-rata kondisi spiritul keseluruhan keluarga yang diamati

SHk : Skor kondisi spiritual keluarga ke-k

$\mathrm{N} \quad$ : Jumlah keseluruhan keluarga yang diamati di suatu wilayah/negara

Sedangkan untuk menghitung nilai spiritual masing-masing keluarga, digunakan formula berikut ini: 
Dimana:

$$
S H=\sum_{n=1}^{n} \frac{\mathrm{H} 1+\mathrm{H} 2+\cdots+\mathrm{Hn}}{\mathrm{MH}}
$$

$\begin{array}{ll}\text { SH } & : \text { skor rata-rata kondisi spiritual keluarga } \\ \text { Hh } & : \text { skor kondisi spiritual anggota keluarga ke-h } \\ \text { MS } & : \text { jumlah anggota keluarga }\end{array}$

Untuk menghitung skor spiritual individu anggota rumah tangga/keluarga, maka digunakan rumus berikut ini:

$$
\mathbf{H i}=\frac{V \text { pi }+V_{f i}+V_{z i}+V_{h i}+V_{g i}}{5}
$$

Dimana:

Hi $\quad$ : skor aktual anggota keluarga ke-i

Vpi : skor shalat anggota keluarga ke-i

Vfi : skor puasa anggota keluarga ke-i

Vzi : skor zakat dan infak anggota keluarga ke-i

Vhi : skor lingkungan keluarga menurut anggota keluarga ke-i

Vgi : skor kebijakan pemerintah menurut anggota keluarga ke-i

Adapun garis kemiskinan spiritual, yaitu nilai SV, sebagaimana telah dijelaskan pada Tabel 1, berada pada skor 3. Setelah diketahui nilai SV (Spiritual Value) dan nilai MV (Material Value), maka kemudian setiap rumah tangga tersebut akan dikelompokkan ke dalam kuadran CIBEST dengan menggunakan kombinasi nilai sebagaimana dinyatakan dalam Tabel 2 . 
Tabel 2. Pengelompokkan Kuandran CIBEST berdasarkan Nilai SV dan MV

\begin{tabular}{|c|c|c|}
\hline Skor Aktual & S Nilai MV & $>$ Nilai MV \\
\hline \multirow{2}{*}{$>$ Nilai SV } & $\begin{array}{c}\text { Kaya Spiritual, Miskin } \\
\text { Material (Kuadran II) }\end{array}$ & $\begin{array}{c}\text { Kaya Spiritual, Kaya } \\
\text { Material (Kuadran I) }\end{array}$ \\
\hline \multirow{2}{*}{$\leq$ Nilai SV } & Miskin Spiritual, Miskin & Miskin Spiritual, Kaya \\
& Material & Material (Kuadran III) \\
& (Kuandran IV) & \\
\hline
\end{tabular}

Sumber : Beik dan Arsyianti (2015)

Setelah diketahui posisi kuadrannya, maka kemudian dapat dilakukan perhitungan nilai indeks yang ada sebagai berikut:

\section{Indeks Kesejahteraan}

$$
\mathbf{W}=\frac{w}{N}
$$

Keterangan:

$$
\begin{array}{ll}
\mathrm{W} & : \text { indeks kesejahteraan } ; 0 \leq \mathrm{W} \leq 1 \\
\mathrm{~W} & : \text { Jumlah keluarga sejahtera (kaya secara material dan spiritual) } \\
\mathrm{N} & : \text { Jumlah populasi rumah tangga yang diobservasi }
\end{array}
$$

\section{Indeks Kemiskinan Material}

$$
\operatorname{Pm}=\frac{M p}{N}
$$

Keterangan:

$\begin{array}{ll}\mathrm{Pm} & : \text { Indeks kemiskinan material } 0 \leq \mathrm{Pm} \leq 1 \\ \mathrm{Mp} & : \begin{array}{l}\text { Jumlah keluarga yang miskin secara material namun kaya } \\ \text { secara spiritual }\end{array} \\ \mathrm{N} & : \text { Jumlah populasi total rumah tangga yang diamati }\end{array}$




\section{Indeks Kemiskinan Spiritual}

$$
\text { Ps }=\frac{5 p}{N}
$$

Keterangan:

$$
\begin{array}{ll}
\text { Ps } & : \text { Indeks kemiskinan spiritual; } 0 \leq \text { Ps } \leq 1 \\
\mathrm{Sp} & : \begin{array}{l}
\text { Jumlah keluarga yang miskin secara spiritual namun kaya } \\
\text { secara material }
\end{array} \\
\mathrm{N} & : \text { Jumlah populasi total rumah tangga yang diamati }
\end{array}
$$

\section{Indeks Kemiskinan Absolut}

$$
\mathrm{Pa}=\frac{A p}{N}
$$

Keterangan :

$\begin{array}{ll}\text { Pa } & : \text { Indeks kemiskinan absolut } 0 \leq P a \leq 1 \\ \text { Ap } & : \begin{array}{l}\text { Jumlah keluarga yang miskin secara spiritual dan juga } \\ \text { material }\end{array} \\ \mathrm{N} & : \text { Jumlah populasi total rumah tangga yang diamati }\end{array}$

Adapun contoh aplikasi dari model CIBEST ini antara lain dapat dilihat pada artikel Beik dan Arsyianti yang berjudul "Measuring Zakat Impact on Poverty and Welfare Using CIBEST Model" yang dipublikasikan dalam Journal of Islamic Monetary Economics and Finance Vol 1 No 2 tahun $2016^{11 .}$

\section{Pustaka Acuan}

Beik, Irfan Syauqi, Arsyianti LD. (2015). Consruction of CIBEST Model as Measurement of Poverty and Welfare Indicesfrom Islamic Perspective. Al-Iqtishad. Vol VII No 1. Link : http://journal.uinjkt.ac.id/index.php/iqtishad/article/view/1361 atau https://www.researchgate.net/publication/280723626_CONSTRUCTION_OF_CI BEST_MODEL_AS_MEASUREMENT_OF_POVERTY_AND_WELFARE_INDICES_FRO M_ISLAMIC_PERSPECTIVE.

Beik, Irfan Syauqi. (2008). "Snapshot Ekonomi Islam Dunia”. Jurnal Muamalah, Vol 5, February 2008, h. 13-46. 
Irfan Sauqi Beik: Islamisasi Ilmu Ekonomi

Beik, Irfan Syauqi. Arsyianti, Laily Dwi. (2016). Ekonomi Pembangunan Syariah.

Jakarta : Rajagrafindo. Bukun ini sedang dalam proses naik cetak untuk edisi revisinya.

Hafidhuddin, Didin. (2007). Peran Pembiayaan Syariah dalam Pembangunan Pertanian di Indonesia. Bogor : IPB Press.

Hafidhuddin, Didin. (2007). Peran Pembiayaan Syariah Dalam Pembangunan Pertanian Di Indonesia. Bogor : IPB Pers.

Hafidhuddin, Didin. (2013). “Analisis Syariah Tentang Konsep Kemiskinan”. Makalah dipresentasikan pada FGD Nasional Pengentasan Kemiskinan, Bogor.

Haneef, Mohamad Aslam. (2013). "Integration and Islamization of Economics". Makalah dipresentasikan pada Workshop Kurikulum dan Deklarasi South East Asian Association of Education and Research Institution for Islamic Economics and Finance di Universitas Muhammadiyah Yogyakarta, 28-29 November.

Hassan, Zubair. (1998). " Islamization of Knowledge: Issues and Agenda”. IIUM Journal of Economics and Management, Vol. 6 No.2.

http://www.journalbankindonesia.org/index.php/JIMF/article/view/524

Sadeq, Abdul Hasan. Dan Ghazali, Aidit. (1992). Readings in Islamic Economic Thought. Malaysia : Longman.

\section{Catatan Akhir:}

\footnotetext{
${ }^{1}$ Sadeq, Abdul Hasan. Dan Ghazali, Aidit. (1992). Readings in Islamic Economic Thought. Malaysia : Longman.

2 Hafidhuddin, Didin. (2007). Peran Pembiayaan Syariah dalam Pembangunan Pertanian di Indonesia. Bogor : IPB Press.

3 Penggunaan istilah ilmu ekonomi syariah atau ilmu ekonomi Islam di Indonesia telah mengundang perdebatan yang cukup tajam. Berbeda dengan di luar negeri yang lebih menggunakan istilah Islamic Economics instead of Shariah Economics. Hal ini dikarenakan oleh proses terbentuknya ekonomi syariah yang ditandai oleh pendirian bank syariah pertama, yaitu Bank Muamalat. Pada saat itu, rezim Orde Baru lebih menyukai penggunaan istilah syariah dibandingkan Islam. Akibatnya, kondisi ini mempengaruhi struktur hukum dan perundang-undangan yang ada, dimana UU yang ada menggunakan istilah syariah. Misalnya, UU No 19/2008 tentang surat Berharga Syariah Negara dan UU No 21/2008 tentang Perbankan Syariah. Namun dalam makalah ini, penulis tidak akan membahas masalah ini dan mengasumsikan bahwa ilmu ekonomi Islam dan ilmu ekonomi syariah adalah dua hal yang sama.

${ }^{4}$ Hassan, Zubair. (1998). “Islamization of Knowledge: Issues and Agenda”. IIUM Journal of Economics and Management, Vol. 6 No.2.

${ }^{5}$ Haneef, Mohamad Aslam. (2013). "Integration and Islamization of Economics". Makalah dipresentasikan pada Workshop Kurikulum dan Deklarasi South East Asian Association of Education and Research Institution for Islamic Economics and Finance di Universitas Muhammadiyah Yogyakarta, 28-29 November.

${ }^{6}$ Beik, Irfan Syauqi. Dan Arsyianti, Laily Dwi. (2016). Ekonomi Pembangunan Syariah. Jakarta :

Rajagrafindo. Bukun ini sedang dalam proses naik cetak untuk edisi revisinya.
} 
Islamiconomic: Jurnal Ekonomi Islam Vol.7 No.2 Juli - Desember 2016

${ }^{7}$ Hafidhuddin, Didin. (2007). Peran Pembiayaan Syariah Dalam Pembangunan Pertanian Di Indonesia. Bogor : IPB Pers.

${ }^{8}$ Beik, Irfan Syauqi. (2008). "Snapshot Ekonomi Islam Dunia". Jurnal Muamalah, Vol 5, February 2008, h. 13-46.

${ }^{9}$ Beik IS, Arsyianti LD. (2015). Consruction of CIBEST Model as Measurement of Poverty and Welfare Indicesfrom Islamic Perspective. Al-Iqtishad. Vol VII No 1. Link :

http://journal.uinjkt.ac.id/index.php/iqtishad/article/view/1361 atau

https://www.researchgate.net/publication/280723626_CONSTRUCTION_OF_CIBEST_MODEL_AS_MEA SUREMENT_OF_POVERTY_AND_WELFARE_INDICES_FROM_ISLAMIC_PERSPECTIVE

${ }^{10}$ Hafidhuddin, Didin. (2013). “Analisis Syariah Tentang Konsep Kemiskinan”. Makalah dipresentasikan pada FGD Nasional Pengentasan Kemiskinan, Bogor.

${ }^{11}$ http://www.journalbankindonesia.org/index.php/JIMF/article/view/524 